\title{
PEMEGANG HAK TENAGA KERJA ASING DALAM PERSPEKTIF HAK ASASI MANUSIA
}

\author{
Chandra Putra Kuriawan \\ Fakultas Hukum Universitas Brawijaya \\ Jl. MT. Haryono No 169 Malang \\ Email: chandraputra.kurniawan@yahoo.com
}

\begin{abstract}
This paper discussed the rights of foreign workers to get employment in terms of the Immigration Act, the Manpower Act, and human rights. The method used a normative conceptual approach. The results of the study showed that in the perspective of human rights, the rights of foreign workers were the rights of workers based on Article 27 paragraph (2) of the 1945 Constitution, namely that each citizen has the right to work and livelihood that was for humanity and article 28 D paragraph (2) of the 1945Constitution, namely that everyone has the right to work and get fair and decent compensation and treatment. The right to work and decent living according to the mandate of the 1945 Constitution stated in the Immigration Act, foreign workers entitled to work and/or businesses to fulfil their needs to live and/or fulfil their families. From this provision, foreigners who intermarry and also their families could try to work in Indonesia in the context of their rights to fulfil the needs of a decent life for him and his family and as a respect for human rights, while the fulfilment of human rights contained in the Manpower Act, it understood that in the sense that the workers can feel their basic rights as workers, the provisions about workers' human rights could be realized, namely equal opportunities and treatment in work relations.
\end{abstract}

Keywords: Human Rights, Foreign Workers,

\begin{abstract}
Abstrak: TulisaninimembahashaktenagakerjaasinguntukmendapatkanpekerjaanditinjaudariUndangUndangKeimigrasian, Undang-UndangKetenagakerjaan, hakasasimanusia. kajian ini menggunakan metode pendekatan konseptual normatif. Hasilkajianmenunjukandidalam perspektifhak asasi manusia pemegang hak tenaga kerja asing yaitu hak pekerja bersumber pada pasal 27 ayat (2) UUD 1945 yaitu tiap-tiap warga negara berhak atas pekerjaan dan penghidupan yang layak bagi kemanusian dan pasal 28 D ayat (2) UUD 1945 yaitu setiap orang berhak untuk bekerja serta mendapat imbalan dan perlakuan yang adil dan layak.Hak atas pekerjaan dan penghidupan yang layak sesuai amanat UUD 1945 tertuang pada Undang-undang Keimigrasian, Tenaga kerja asing berhak atas pekerjaan dan/ atau usaha memenuhi kebutuhan guna untuk hidup dan/atau memenuhi keluarganya. Dari ketentuan itu maka bagi orang asing pelaku kawin campur dan keluarganya bisa berusaha dalam arti atau bekerja di Indonesia dalam rangka sebagaimana haknya guna untuk memenuhi kebutuhan hidupyang layak bagi dia dan keluarganya serta sebagai penghormatan terhadap hak asasi manusia, Sedangkan pemenuhan hak asasi manusia yang tertuang pada Undang-undang Ketenagakerjaan memahami dalam arti pihak pekerja dapat merasakan hak-hak dasarnya sebagai pekerja, ketentuan tentang hak asasi pekerja sudah dapat terlaksana, yakni kesempatan dan perlakuan yang sama dalam hubungan kerja.
\end{abstract}

Kata Kunci: Hak Asasi Manusia, Tenaga Kerja Asing, Undang-undangDasar

Mulainya industrialisasi dimuka bumi, disebut sebagai globalisasi namun juga menjadi fenomena yang lumrah tidak hanya dalam sejarahnya tetapi dewasa ini investasi ke berbagai sendi-sendi kehidupan di penjuru dunia mendorong pergerakan aliran modal Tenaga kerja asing termasuk di dalam aspek Ketenagakerjaan yang mengakibatkan terjadinya migrasi penduduk.Dalam mewujudkan tertib hukum di dalam mempekerjakan tenaga kerja asing dalam pembangunan daerah serta meningkatkan mutu tenaga kerja lokal. Untuk keperluan tersebut, Tenaga Kerja Asing 
(selanjutnya disebut TKA) perlu membawa serta beberapa tenaga kerja dari negara lain atau negara asal guna untuk bekerja, para pemilik modal maupun sebagai pengusaha, maka diperlukan suatu peraturan yang mengatur tenaga kerja asing, dari peraturan ketenagakerjaan dalam rangka mencegah masuknya tenaga kerja asing illegal yang dapat merugikan perekonomian daerah serta mengurangi lapangan kerja bagi tenaga kerja lokal. Oleh karena itu perlunya suatu pengaturan dalam menciptakan program peningkatan produktivitas tenaga kerja lokal dan pendapatan daerah merupakan suatu keharusan.

Indonesia merupakan negara hukum yang mana di dalam negara hukum selalu ada pengakuan dan perlindungan terhadap hak asasi manusia. Semua manusia akan mendapat perlakuan yang sama kedudukannya dalam hukum, sosial, ekonomi, dan kebudayaan (Nazmi, 1992:50).

Dalam hubungan antara sesama warganegara ataupun hubungan antara negara (penguasa) dan warganegara (rakyat), hubungan penguasa dengan rakyatnya ataupun hubungan rakyat dengan sesama rakyat disini HAM ialah merupakan muatan standar normatif untuk mengatur maupun berisi hak-hak dasar manusia. Oleh karena itu, terhadap hak-hak rakyat dari kesewenang-wenangan penguasa, tujuan HAM mempunyai makna penting untuk memberikan perlindungan. Terdapat dua makna yang terkandung dalam HAM, pertama, HAM melekat dalam diri setiap manusia sejak dilahirkan ke dunia yang merupakan hak alamiah. Kedua, HAM sesuai dengan kodrat kemanusiaannya yang luhur ini adalah merupakan instrumen untuk menjaga harkat serta martabat manusia.

Tenaga Kerja Asing yang telah digunakan di indonesiamengalami perubahan sesuai dengan zamanya. Ditinjau dari aspek hukum ketenagakerjaan, pada dasarnya adalah untuk menjamin dan memberi kesempatan kerja yang layak bagi warga negara Indonesia diberbagai lapangan dan level ini adalah bertujuan untuk mengatur mengenai Tenaga Kerja Asing. Dikarenakan dalam prosedur perizinan hingga pengawasan Tenaga Kerja Asing dilakukan melalui mekanisme dan prosedur yang ketat dimulai dengan seleksi memperkerjakan Tenaga Kerja Asing di Indonesia.

Didalam undang-undang mengenai masuk dan keluar wilayah Indonesia, dokumen perjalanan Republik Indonesia berupa, tanda masuk, visa dan izin tinggal, tindakan administratif keimigrasian, pengawasan keimigrasian, serta penyidikan ini diperuntukkan kepada Tenaga kerja orang asing yang akan masuk dan bertempat tinggal di Indonesia.Undang-Undang Nomor 6 Tahun 2011 Tentang Keimigrasian ini mendorong meningkatnya mobilitas penduduk dunia yang menimbulkan berbagai dampak, dilihat dari Perkembangan globalisasi yang merugikan maupun yang menguntungkan kehidupan bangsa dan kepentingan negara Indonesia, sehingga diperlukan peraturan perundang-undangan guna untuk menjamin kepastian hukum keimigrasian terhadap Tenaga Kerja Asing di Indonesia.

Pasal 52 huruf e dan huruf $f$ dan pemegang Izin Tinggal Tetap sebagaimana dimaksud dalam Pasal 54 ayat (1) huruf $b$ dan huruf $d$ UndangUndang Nomor 6 Tahun 2011 Tentang Keimigrasian Pasal 61 menentukan bahwa Pemegang Izin Tinggal Terbatas sebagaimana dimaksud dalam dapat melakukan usaha dan/atau pekerjaan untuk memenuhi kebutuhan hidup dan/atau keluarganya. Adapun bunyi Pasal 52 huruf e dan $\mathrm{f}$ sebagaimana yang telah diatur bahwa Izin Tinggal Terbatas (ITAS) diberikan kepada orang asing yang kawin secara sah dengan warga negara Indonesia atau anak dari orang asing yang kawin secara sah dengan warga negara Indonesia. Demikian jugakepada keluarga karena perkawinan campuran ditentukan bahwa Izin Tinggal Tetap dapat diberikan sebagaimana tertuang dalam Pasal 54 huruf (b) dan (d) dan kepada orang asing eks warga negara Indonesia dan eks subyek anak berkewarganegaraan ganda Republik Indonesia. Dari ketentuan diatas maka bagi orang asing pelaku kawin campur dan keluarganya bisa bekerja dan berusaha di Indonesia dalam rangka sebagaimana untuk memenuhi kebutuhan hidup yang layak bagi dia dan keluarganya (Hamidi, 2015: 15).

Disisi lain Pasal 42 Undang-undang Republik Indonesia Nomor 13 Tahun 2003 Tentang Ketenagakerjaan (selanjutnya disebut Undang undang Ketenagakerjaan) mengatur lain yaitu mengatur hak tenaga kerja asing dalam haknya bekerja di indonesia.Adapun bunyi ayat tersebut pada ayat (1) Setiap pemberi kerja yang mempekerjakan tenaga asing wajib memiliki izin tertulis dari Menteri atau Pejabat yang ditunjuk, pada ayat (2) Pemberi kerja orang perseorangan dilarang memperkerjakan tenaga kerja asing, pada ayat (3) Kewajiban memiliki izin sebagaimana dimaksud pada ayat (1), tidak berlaku lagi 
perwakilan negara asing yang mepergunakan tenaga kerja asing sebagai pegawai diplomatik dan konsuler, pada ayat (4) Tenaga kerja asing dapat dipekerjakan di Indonesia hanya dalam hubungan kerja untuk jabatan tertentu dan waktu tertentu, pada ayat (5) Ketentuan mengenai jabatan tertentu dan waktu tertentu sebagaimana dimaksud pada ayat (4) ditetapkan dengan Keputusan Menteri, serta pada ayat (6) Tenaga kerja asing sebagaimana dimaksud pada ayat (4) yang masa kerjanya habis dan tidak dapat diperpanjang dapat digantikan oleh tenga kerja asing lainnya.

Undang-undang Ketenagakerjaan Salah satu yang dibawa adalah pengaturan mengenai hubungan kerja. Undang-undang ini merinci makna pekerjaan. Pekerjaan merupakan sesuatu yang amat sentral. Dirincinya atau dibatasinya pekerjaan ini merupakan bentuk menjamin kepastian hukum sebagaimana tertuang dalam Undang-undang Nomor 13 Tahun 2003 namun tidak dirincinya dan dibatasinya adalah sesuatu yang logis menurut legal reasoning atau penalaran hukum sebagaimana di dalam pasal 61 Undang-undang 6 Tahun 2011 Tentang keimigrasianm. Dikatakan demikian justru akan mempersulit pelaksanaan dan pengembangan karena apabila diberikan pengertian atau batasan tertentu (Budiono: 2012: 139).

Berdasarkan latar belakang diatas maka dapat dirumuskan yaitu Pemegang hak tenaga kerja asing dalam perspektif hak asasi manusia. Maka dalam kajian ini akan dilakukan metode pendekatan konseptual normatif Sebagai upaya untuk menjawab permasalahan di atas. Hak Pekerja bersumber pada pasal 27 ayat (2) UUD 1945 dan pasal 28 D ayat (2) UUD 1945 yaitu pasal 27 ayat (2) berbunyi yaitu tiap-tiap warga negara berhak atas pekerjaan dan penghidupan yang layak bagi kemanusian sedangkan pasal 28 D berbunyi setiap orang berhak untuk bekerja serta mendapat imbalan dan perlakuan yang adil dan layak (Wijayati, 2012: 212).

\section{HASIL DAN PEMBAHASAN}

\section{Hak Tenaga Kerja Asing Untuk Mendapatkan Pekerjaan Di Indonesia Dalam Undang-Undang Keimigrasian}

Subjek hukum terhadap selaku pemikul hakhak dan kewajiban-kewajiban, manusia dapat melakukan tindakan demi tindakan hukum berdasarkan dengan kemampuan dan kewenangan yang telah dimilikinya. Dalam pergaulan ditengah hukum masyarakat, banyak terjadi hubungan hukum yang muncul melalui adanya tindakan demi tindakan hukum dari subjek hukum itu sendiri. Tindakan hukum ini merupakan awal lahirnya hubungan hukum yakni interaksi antara subjek hukum dengan yang memiliki relevansi hukum ataupun yang mempunyai akibat-akibat hukum. Agar selalu hubungan hukum antar subjek hukum itu berjalan secara harmonis, seimbang, dan adil, dalam arti bahwa setiap subjek hukum mendapatkan apa yang akan menjadi haknya dan menjalankan kewajiban yang telah dibebankan kepadanya. Hukum tampil sebagai aturan main dalam mengatur hubungan hukum tersebut (Ridwan, 2006: 265).

Pasal 61 Undang-undang Keimigrasian memberikan peluang kepada orang asing sebagai tenaga kerja asing dengan menikah dengan warga negara Indonesia untuk melakukan pekerjaan dan/ atau usaha untuk memenuhi kebutuhan hidup dan keluarganya. Pada prinsipnya tenaga kerja asing, dikenakan pembatasan-pembatasan tertentu, yaitu khususnya menyangkut terhadap hak akan tetapi Undang-undang keimigrasian memerikan hak bekerja sebagaimana guna untuk memenuhi kebutuhan hidup dan keluarganya, sehingga yang merupakan penduduk Indonesia mempunyai hak dan kewajiban yang berbeda dengan hak dan kewajiban tenaga kerja Indonesia yaitu warga negara Indonesia sendiri.

Adapun hak bagi orang asing yang bekerja di Indonesia adalah sebagai berikutPertama, Mendapat fasilitas layaknya sebagai seorang tenaga kerja yang disponsori istri. Kedua, Mendapat Upah yang layak dan memenuhi standar upah baik secara lokal, nasional, regional, ataupun secara internasional. Ketiga, Berhak untuk menentukan pilihan dan jalan hidupnya sendiri termasuk menentukan pasangan hidupnya baik sebagai suami atau istri. Keempat, Berhak untuk mendapat perlakuan yang layak sebagai seorang warga masyarakat yang tentunya juga sangat memerlukan kehidupan bersama dengan orang lain yang berbeda warga negara (Anwar, 2011: 70).

Kewajibanorang asing yang bekerja di Indonesia adalah: (a) berkewajiban menaati semua peraturan yang berlaku, (b) siap dideportasi ke negara asal atau keluar negeri apabila habis masa ijin tinggaldan habisnyamasa perpanjangan ijin tinggal, (c) apabila telah melangsungkan 
perkawinan dengan warga negara Indonesia, siap menentukan kewarganegaraanya jika menginginkan. Setiap tenaga kerja asing yang beritikad baik diberikan jaminan dan perlindungan keamanan yang meliputi harta benda, jiwa, dan usahanya. Oleh karena itu, sewajarnya apabila orang asing yang bertempat tinggal di Indonesia membantu keuangan negara dengan melalui pajak bangsa asing (Wijayanti, 2011: 150).

\section{Hak Tenaga Kerja Asing Untuk Mendapatkan Pekerjaan Di Indonesia Dalam Undang-Undang Ketenagakerjaan}

Mempekerjakan tenagakerjaasing (TKA) tersebut tidak akan dapat dihindarkan. Menurut Budiono, ada beberapa tujuan penempatan TKA selama berada di Indonesia, yaitu;Pertama, Guna untuk memenuhi kebutuhan tenaga kerja terampil dan profesional Terhadap bidang- bidang tertentu yang belum dapat diisi oleh TKI. Kedua, Mempercepat proses demi proses pembangunan nasional dengan jalan mempercepat proses alih teknologi ataupun alih ilmu pengetahuan, terutama di bidang industri. Ketiga, Memberikan perluasan kesempatan terhadap tenaga kerja bagi TKI. Keempat, Meningkatkan investasi asing sebagai penunjang modal terhadap pembangunan di Indonesia (BudionodanRachmat, 2005: 115).Faktor ini merupakan hak asasi manusia yang dianggap tidak dapat dipisahkan terhadap manusia untuk mengeksplorasi potensi mereka sampai batas maksimal. 'We know due to this factor human rights are considered as inalienable the human being to explore their potentiality to fullest extent'(Roy, 2016: 212).

Pasal 42 Undang-undang Republik Indonesia Nomor 13 Tahun 2003 Tentang Ketenagakerjaan (selanjutnya disebut Undangundang Ketenagakerjaan) Tenaga kerja asing dalam memperoleh haknya serta tenaga kerja asing terhadap haknya juga dibatasi untuk bekerja di indonesia yaitu dengan ketentuan bekerja di Indonesia dengan izin tertulis dari menteri atau pejabat yang ditunjuk, didalam kerja orang perorangan dilarang memperkerjakan tenaga kerja asing artinya tidak dapat orang perorangan tersebut memberi pekerjaan terhadap tenaga kerja asing, Adapun kewajiban memiliki izin tidak berlaku lagi bagiperwakilan negara asing yang mempergunakan tenaga kerja asing sebagai pegawai diplomatik dan konsuler, Tenaga kerja asing dapat dipekerjakan di Indonesia hanya dalam hubungan kerja untuk jabatan tertentu dan waktu tertentu, maka tidak ada tenaga kerja asing yang berstatus warga negara asing yang selama hidupnya bekerja di Indonesia dengan menduduki kedudukan pekerjaan yang telah ditentukan, serta terhadap tenaga kerja asing yang masa kerjanya telah habis dan tidak dapat diperpanjang dapat digantikan oleh tenaga kerja asing lainnya.

Tujuan terhadap penggunaan tenaga kerja asing adalah sebagai guna untuk memenuhi kebutuhan tenaga kerja yang terampil dan professional terhadap bidang tertentu yang belum dapat diduduki oleh tenaga kerja lokal yakni tenaga kerja Indonesia (TKI) serta sebagai tahapan didalam mempercepat proses pembangunan nasional maupun daerah dengan jalan mempercepat alih ilmu pengetahuan dan teknologi serta meningkatkan investasi asing terhadap kehadiran TKA di Indonesia untuk penunjang pembangunan di Indonesia walaupun pada kenyataannya dimana perusahaan-perusahaan yang ada di Indonesia baik itu perusahaanperusahaan yang berstatus perusahaan swasta asing ataupun swasta nasional wajib menggunakan tenaga ahli bangsa Indonesia sendiri (Abdussalam, 2008:322).

Pemberi kerja tenaga kerja asing yangberbadan hukum atau badan-badan lainnya yang telah ditetapkan dalam mempekerjakan tenaga kerja asing harusmembayar upah atau imbalan dalam bentuk lain, hal tersebut tercantum pada Pasal 4 Peraturan Menteri Tenaga Kerja dan Transmigrasi Republik Indonesia Nomor 35 Tahun 2015 Tentang Tata Cara Penggunaan Tenaga Kerja, pemberi kerja tenaga kerja asing meliputi badan-badan internasional, instansi pemerintah, perwakilan negara asing, organisasi internasional, kantor perwakilan dagang asing, kantor perwakilan perusahaaan asing, kantor perwakilan berita asing, perusahaan swasta asing, badan usaha asing yang terdaftar di instansi yang berwenang, Lembaga sosial, keagamaan, pendidikan dan kebudayaan, dan Usaha jasa impresariat serta Pemberi TKA yang berbentuk persekutuan perdata, persekutuan firma (Fa), usaha bersama / associate (UB), persekutuan komanditer (CV), koperasi dilarang memperkerjakan TKA kecuali diatur dalam undang-undang dan usaha dagang (UD), Badan hukum yang didirikan berdasarkan hukum Indonesia dalam bentuk Perseroan Terbatas atau Yayasan. 
Ditinjau dari aspek hukum ketenagakerjaan tujuan pengaturan mengenai Tenaga Kerja Asing pada dasarnya adalah memberi dan untuk menjamin kesempatan kerja yang layak bagi warga negara Indonesia di berbagai tingkatan dan lapangan. Sehingga dalam hal mempekerjakan Tenaga Kerja Asing di Indonesia harus melalui prosedur yang ketat dimulai dengan seleksi dilakukan melalui mekanisme dan prosedur perizinan hingga pengawasan.

\section{Hak Tenaga Kerja Asing Dalam Mendapatkan Pekerjaan Di Indonesia Dalam Perspektif Hak Asasi Manusia}

Hak merupakan sesuatu yang harus diperoleh bagaimanapun mestinya. Menurut teori McCloskey dinyatakan bahwa pemberian hak adalah untuk dilakukan, dimiliki, atau sudah dilakukan. Sedangkan dalam teori Joel Feinberg dinyatakan bahwa pemberian hak penuh merupakan kesatuan dari klaim yang absah (keuntungan yang didapat dari pelaksanaan hak yang disertai pelaksanaan kewajiban). Dengan demikian keuntungan dapat diperoleh dari pelaksanaan hak bila disertai dengan pelaksanaan kewajiban. Hal itu berarti antara hak dan kewajiban merupakan dua hal yang tidak dapat dipisahkan dalam perwujudannya. Karena itu ketika seseorang menuntut hak juga harus melakukan kewajiban (Tim ICCE UIN, 2003: 200).

John Locke menyatakan bahwa hak asasi manusia adalah hak-hak yang diberikan langsung oleh Tuhan Yang Maha Pencipta sebagai hak yang kodrati. Oleh karenanya, maka tidak ada kekuasaan apapun di dunia yang dapat mencabutnya. Hak ini sifatnya sangat mendasar (fundamental) bagi hidup dan kehidupan manusia dan merupakan hak kodrati yang tidak bisa terlepas dari dan dalam kehidupan manusia (Effendi, 1994: $3)$.

Hak Asasi Manusia (HAM) adalah keberadaan manusia sebagai makhluk Tuhan Yang Maha Esa dan merupakan anugerah-Nya yang wajib dihormati, maka dari itu harus dijunjung tinggi yang mana dilindungi oleh hukum, negara, pemerintah dan setiap orang demi kehormatan serta perlindungan harkat serta martabat manusia sebagai seperangkat hak yang telah melekat pada hakikat dengan merujuk pada Pasal 1 UndangUndang Nomor 39 Tahun 1999 tentang Hak Asasi Manusia.
Berdasarkan pernyataan terhadap hak asasi manusia dapat dimunculkan beberapa rumusan pengertian HAM tersebut, diperoleh suatu kesimpulan bahwa HAM merupakan suatu hak yang melekat pada diri manusia yang mana bersifat kodrati dan fundamental sebagai suatu anugerah Tuhan yang harus dijunjung tinggi, dihormati, dijaga dan dilindungi oleh setiap individu maupun kelompok, masyarakat atau negara. Dengan demikian hakikat penghormatan dan perlindungan terhadap HAM ialah menjaga keselamatan terhadap eksistensi manusia secara utuh melalui berbagai aksi keseimbangan yaitu keseimbangan antara hak dan kewajiban yang akan dilaksanakan dan dijalankan, serta keseimbangan antara kepentingan umum dan kepentingan perseorangan (Tim ICCE UIN, 2003: 200).

Terdapat Rumusan HAM dalam UUD 1945 dapat dibagi ke dalam beberapa aspek yaitu aspek HAM berkaitan dengan hidup dan kehidupan, HAM berkaitan dengan pendidikan, HAM berkaitan dengan keluarga, ilmu pengetahuan, dan teknologi, HAM berkitan dengan kebebasan beragama dan meyakini kepercayaan, HAM berkaitan dengan pekerjaan, kebebasan bersikap, berpendapat, dan berserikat, HAM berkaitan dengan rasa aman dan perlindungan dari perlakuan yang merendahkan derajat dan martabat manusia, HAM berkaitan dengan informasi dan komunikasi, HAM berkaitan dengan kesejahteraan sosial, HAM berkewajiban menghargai hak orang dan pihak lain serta HAM berkaitan dengan persamaan dan keadilan.

Berlandaskan rumusan HAM dalam UUD 1945, Hak atas pekerjaan dan penghidupan yang layak sesuai amanat UUD 1945 tertuang pada Undang-undang Keimigrasian, Tenaga kerja asing dapat usaha untuk memenuhi kebutuhan hidup dan/atau keluarganya dan/atau dapat melakukan pekerjaan.Dari ketentuan diatas maka bagi orang asing pelaku kawin campur dan keluarganya bisa berusaha dan bekerja di Indonesia dalam rangka untuk memenuhi kebutuhan hidup yang layak bagi dia dan keluarganya serta sebagai penghormatan terhadap hak asasi manusia Sedangkan pemenuhan hak asasi manusia yang tertuang pada Undang-undang Ketenagakerjaan memahami dalam arti pihak pekerja dapat merasakan hakhak dasarnya sebagai pekerja, yaitu kesempatan dan perlakuan yang sama dalam hubungan kerja. ketentuan tentang hak asasi pekerja sudah dapat terlaksana. 
Kesetaraan adalah prinsip dasar yang memastikan bahwa setiap manusia dilahirkan bebas dan setara, layak menerima tingkat penghirmatan yang sama dan setiap manusia memiliki hak yang sama, serta non diskriminasi bahwa tidak ada seorangpun ditolak hak asasinya karena faktor etnis asal, usia, dan sebagainya maupun jenis kelamin. Inilah didasarkan pada prinsip bahwa setiap orang dilahirkan setara dalam harkat dan hak-haknya.

Dalam wacana modern, hak asasi manusia dibagi menjadi dua wewenang yang diberikan oleh nilai tertentu dan undang-undang kepada seseorang atas sesuatu tertentu, yakni:

a. Menurut kelahirannya, seperti: hak hidup, hak kebebasan pribadi dan hak bekerja ini adalah Hak asasi alamiah manusia sebagai manusia

b. Karena hukum merupakan seperti: hak memiliki, hak berumah-tangga, hak mendapat keamanan, hak mendapat keadilan dan persamaan hak. Ini adalah hukum hak asasi yang diperoleh manusia sebagai bagian dari masyarakat sebagai individu masyarakat dan sebagai anggota keluarga, Norma umum yang berlaku secara setara bagi setiap orang sesuai dengan prinsip kesetaraan di depan hukum (Muktiono, 2015: 343).

Tenaga kerja asing di Indonesia harus benarbenar sah dalam arti memiliki status kedudukan yang sah (termasuk dokumen yang diperlukan) dan tenaga kerja asing bagi pembangunan nasional Indonesia dimaksud harus benar-benar memberi manfaat.Sehingga dalam implementasinya yang seharusnya hak atas pekerjaan terdapat mekanisme dimana didalam menunaikan tugasnya untuk menetapkan bagaimana standar kehidupan yang layak bagi warga negara. Walaupun harus diakui bahwa ini merupakan suatu kesulitan yang harus dihadapi negara berkenaan dengan hak asasi manusia berupa hak pekerja dan hak atas pekerjaan. Dalam konteks penempatan Tenaga Kerja yang paling utama adalah persoalan akses atas pekerjaan, jaminan perlindungan bagi tenaga kerja, bebas dari pelanggaran hak asasi manusia seperti kerja paksa, praktek perbudakan dan praktek-praktek yang disamakan dengan perbudakan, jeratan hutang ( debt debodage), perdagangan orang ( trafficking ), pernikahan paksa dan pengantin pesanan (Suryani, 2013: 73).

Pemerintah mempunyai kewajiban untuk menghormati, melindungi, menegakkan dan memajukan hak asasi manusia, baik yang diatur dalam undang-undang hak asasi manusia maupun peraturan perundang-undangan lain, dan hukum internasional tentang hak asasi manusia yang telah diterima dan diratifikasi oleh Negara Republik Indonesia. Upaya yang dilakukan pemerintah dalam memenuhi kewajiban dan tanggung jawabnya adalah mengambil langkah-langkah implementasi yang konkrit atas berbagai instrumen hukum maupun kebijakan yang berkategori di bidang hak asasi manusia dari segi politik, hukum, ekonomi, sosial budaya, keamanan serta segi lain yang terkait dan pertahanan (Suryani, 2013: 73).

\section{SIMPULAN}

1. Hak atas pekerjaan dan penghidupan yang layak sesuai amanat UUD 1945 tertuang pada Undang-undang Keimigrasian, Tenaga kerja asing dapat melakukan usaha untuk memenuhi kebutuhan hidup dan/atau keluarganya serta terhadap pemenuhan terhadap pekerjaan. Dari ketentuan diatas maka bagi orang asing pelaku kawin campur dan keluarganya bisa berusaha dan bekerja di Indonesia dalam rangka untuk memenuhi kebutuhan hidup yang layak bagi dia dan keluarganya serta sebagai penghormatan terhadap hak asasi manusia Sedangkan pemenuhan hak asasi manusia yang tertuang pada Undang-undang Ketenagakerjaan memahami dalam arti pihak pekerja dapat merasakan hak-hak dasarnya sebagai pekerja, yaitu kesempatan dan perlakuan yang sama dalam hubungan kerja. ketentuan tentang hak asasi pekerja sudah dapat terlaksana,

2. Hak asasi manusia adalah hak yang melekat dengan kuat di dalam diri manusia, keberadaan Hak asasi manusia diyakini sebagai bagian yang tak terpisahkan dari kehidupan manusia. Hak asasi manusia sebagai hak-hak dasar yang dimiliki setiap manusia untuk semata mata karena dia adalah manusia, didasarkan pada hak-haknya dan prinsip bahwa setiap orang dilahirkan setara dalam harkat dan martabat. Kesetaraan adalah prinsip dasar yang memastikan bahwa setiap manusia dilahirkan untuk bebas dan berposisi setara dalam berkehidupan, setiap manusia memiliki hak yang sama dimana layak menerima tingkat penghormatan yang sama, dan non diskriminasi bahwa tidak ada seorangpun akan ditolak hak asasinya karena faktor etnis asal, usia, dan sebagainya maupun jenis kelamin. 


\section{DAFTAR RUJUKAN}

Achmad Mahfud, Mahdi Bin, “Perlindungan Hukum Bagi Pekerja Migran Dalam Perspektif Hak Asasi Manusia" Disertasi Program Doktor Ilmu Hukum Fakultas Hukum Universitas Brawijaya, Malang, 2015, Dipublikasikan, hlm 119.

Astolegowo. "Harmonisasi pengaturan pemberian jangka waktu hak pakai bagi warga negara asing". Arena Jurnal Vol. 10 No. 1 (April 2017): 110.

Budiono, Abdul Rachmat, Hukum Perburuhan Di Indonesia, PT. Rajagrafindo Persada. Jakarta. 2005.

Effendi, Masyhur. Dimensi dan Dinamika Hak Asasi Manusia dalam Hukum Nasional dan Internasional, Jakarta, Ghalia Indonesia. 1994.

Hamidi, Jazim. Hukum Keimigrasian Bagi Orang Asing di Indonesia, Sinar Grafika, Jakarta. 2015.

HR Abdussalam, Hukum Ketenagakerjaan, Penerbit Restu Agung, Jakarta. 2008.

Muktiono, "Kritik Konseptualisasi Pemegang Hak dan Kewajiban dalam Undang-Undang Hak Asasi Manusia". Arena Jurnal Vol. 8 No. 3 (Desember 2015) : 343.

Nazmi, Didi. Konsepsi Negara Hukum. Angkasa Raya: Padang. 1992.

Prentha, Bahria, "Kebijakan Formulasi Pidana Kerja Sosial Terhadap Anak Sebagai Pelaku Tibdak Pidana Dalam Rana Perlindungan Anak", Ringkasan Disertasi
Ilmu Hukum, Program Pascasarjan Doktor Ilmu Hukum, Malang:UB,2017, Belum Di Publikasikan, hlm 48.

Rachmad Budiono, Abdul,'Makna 'Perintah' Sebagai Salah Satu Unsur Hubungan Kerja Menurut Undang-Undang Nomor 13 Tahun 2003 Tentang Ketenagakerjaan", Arena Jurnal Vol.3 No. 2 (Agustus 2012):139.

Ridwan, Hukum Administrasi Negara, Jakarta, Raja Grafindo Persada, 2006, hlm. 265.

Subir Kumar Roy. " The Principle Of Sustainable Development, Human Rights And Good Governance, " Brawijaya Law Journal Year 2 Vol. 3 (Februari-Maret 2016): 212

Suryani H, Any, “ Tanggung Jawa Negara Terhadap Korban Perdagangan Orang (Human Trafficking) dari Perspektif Hak Asasi Manusia" Disertasi Program Doktor Ilmu Hukum Fakultas Hukum Universitas Brawijaya, Malang, 2013, Dipublikasikan hlm 73.

Tim ICCE UIN Jakarta. Demokrasi, Hak Asasi Manusia dan Masyarakat Madani, Jakarta : Prenada Media. 2003.

Wijayati, Asri." Menuju Sistem Hukum Perburuhan Indonesia Yang Berkeadilan", Arena Jurnal Vol.6 No. 3 (Desember 2012): 212.

Wijayanti, Herlin, Hukum Kewarganegaraan dan Keimigrasian, Malang, Bayu Media, Publishing, 2011. 